
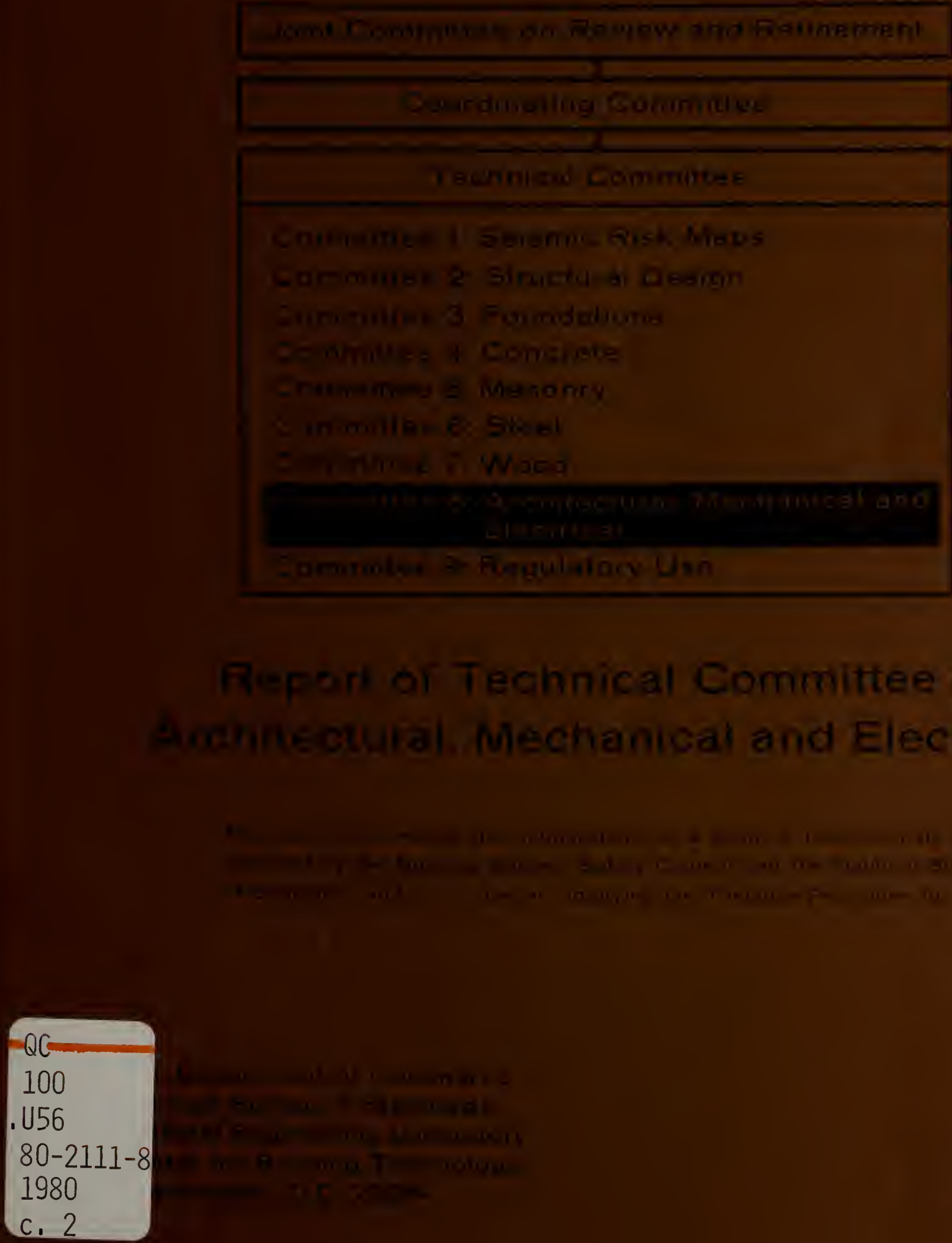

Refarl of Technical Committee 8 : Whectural. Mechanical and Electricai 
- 
REVIEW AND REFINEMENT OF ATC 3-06 TENTATIVE SEISMIC PROVISIONS

REPORT OF TECHNICAL COMMITTEE 8: ARCHITECTURAL, MECHANICAL AND ELECTRICAL

Robert Sockwe11, Chairman, American Institute of Architects

Mark Swatta, Vice Chairman, Interagency Committee on Seismic Safety in Constuction

Thomas K. Faison, Secretary, National Bureau of Standards

James R. Shaver, Assistant Secretary, National Bureau of Standards

Bruce C. Olsen, American Socity of Civil Engineers

Shigehi Hiratsuka, American Socity of Heating Refrigerating and Air

Conditioning Engineers

Philip Lathrap, American Society of Mechanical Engineers

Stephen D. Heath, American Society of Plumbing Engineers

Joseph A. Wintz, Brick Institute of America

George Gibson, National Elevator Industry, Inc.

Tom Wosser, Applied Technology Council

Christopher Arnold, Building Seismic Safety Council

Prepared for use by:

BUILDING SEISMIC SAFETY COUNCIL

Sponsored by:

FEDERAL EMERGENCY MANAGEMENT AGENCY

Center for Building Technology

National Bureau of Standards

Washington, D.C. 20234

October 1980

U.S. DEPARTMENT OF COMMERCE, Phillip M. Klutznick, Secretary

Luther H. Hodges, Jr., Deputy Secretary

Jordan J. Baruch, Assistant Secretary for Productivity,

Technology and Innovation

NATIONAL BUREAU OF STANDARDS, Ernest Ambler, Director 

The TENTATIVE PROVISIONS FOR THE DEVELOPMENT OF SEISMIC REGULATIONS FOR BUILDINGS were developed by the Applied Technology Council to present, in one comprehensive document, current state-of-knowledge pertaining to seismic engineering of buildings. The TENTATIVE PROVISIONS are in the process of being assessed by the building community. This report is one of a series of reports that document the deliberations of a group of professionals jointly selected by the Building Seismic Safety Council and the National Bureau of Standards and charged with reviewing the TENTATIVE PROVISIONS prior to the conduct of trial designs. The report contains recommendations and records of the committee charged with the review of the material related to architectural, mechanical and electrical provisions. The committee made seven general recommendations for revision and one recommendation for the addition of a new section on elevator design requirements. These recommendations by Committee 8 were made to the parent group, the Joint Committee on Review and Refinement, and their action on these recommendations is documented in a companion report.

Keywords: Architectural; electrical; elevators; mechanical; seismic coefficients. 


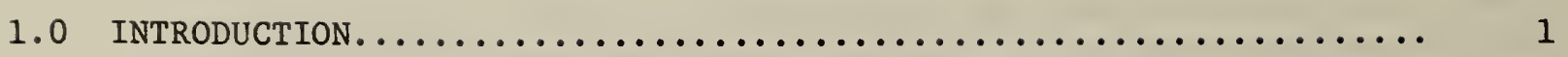

1.1 General......................................... 1

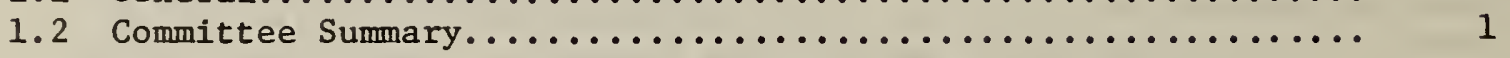

2.0 Committee actions.................................. 4

2.1 Recommendations for Change........................ 4

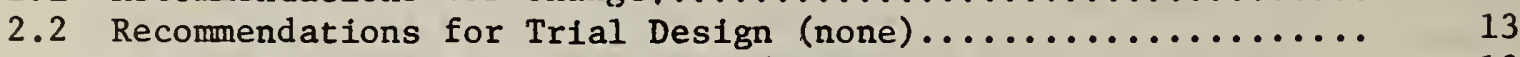

2.3 Recommendations for Commentary (none).................. 13

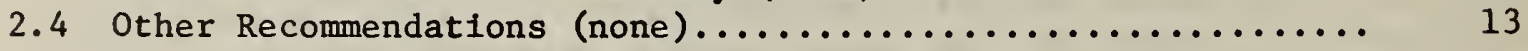

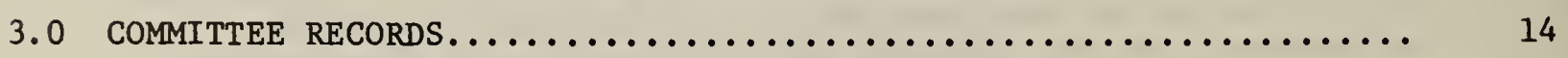

3.1 Minutes of Meetings............................... 14

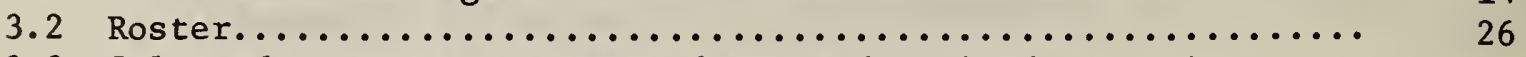

3.3 Selected Committee Correspondence and Applied Technology 


\subsection{Genera 1}

The Tentative Provisions for the Development of Seismic Regulations were developed by the Applied Technology Council (ATC) in an effort that included a wide range of experts in the actual drafting of the provisions. Two external review drafts were circulated to a large portion of the interested and informed community of eventual users. However, because the Tentative Provisions were innovative, doubts about them existed. Consequently, an attempt was made to investigate these doubts and to improve the Tentative Provisions where possible before an expensive assessment of the Tentative Provisions was undertaken by conducting trial designs.

This review and refinement project was planned and conducted by the National Bureau of Standards with the advice and approval of the Building Seismic Safety Council, a private sector organization formed in 1979 for the purpose of enhancing public safety by providing a national forum to foster improved seismic safety provisions for use by the building community.

The assessment of the Tentative Provisions was performed using the committee structure shown in figure 1. Nine Technical Committees were formed with interests that collectively cover the Tentative Provisions. The Joint Committee on Review and Refinement consists of all voting members of the Technical Committees. The chairmen of the Technical Committees form a Coordinating Committee.

Membership of each Technical Committee is made up of representatives of organizations that have particular interest in the Tentative Provisions; the participants are listed in the committee membership section of this report.

In addition to the voting members, each Technical Committee includes a non-voting member from each of the following organizations: The Applied Technology Council (ATC), the Building Seismic Safety Council (BSSC) and the National Bureau of Standards (NBS). The ATC representative served as a technical resource to the committee since he was closely involved with the development of the provisions of interest to the committee. The NBS representative was the technical secretary throughout the effort. The BSSC representative provided a link with the Building Seismic Safety Council, which will be involved in trial designs and evaluations.

\subsection{Committee Summary}

The task of Technical Committee 8 (T.C. 8) was to review the material in Chapter 8 (Architectural, Mechanical and Electrical Components and Systems) of ATC 3-06 and recommend modifications or refinements if felt necessary prior to proceeding to trial designs. The charge to the committee was to consider changes that were technical in nature and would improve the presentation or would assist in carrying out Phase II trial design

objectives. 


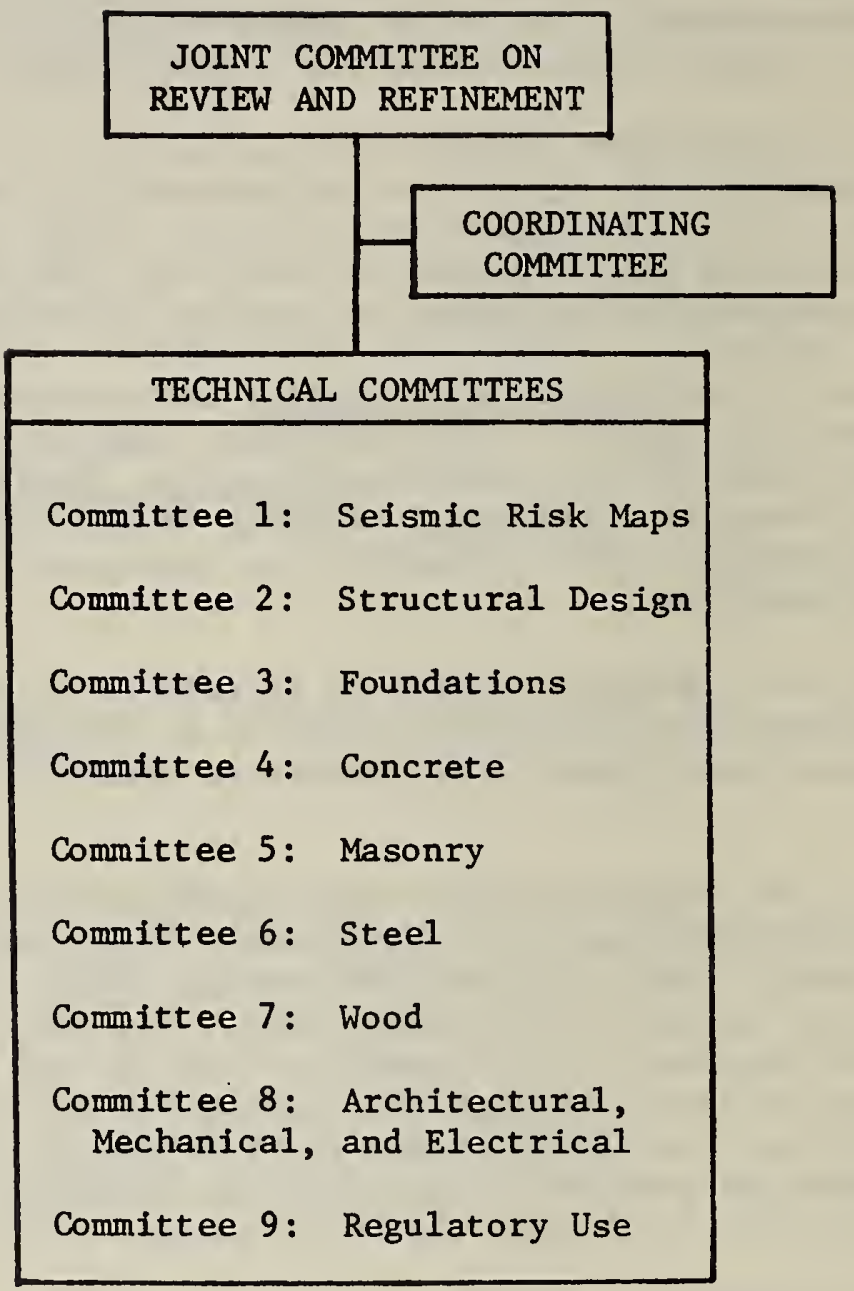

Figure 1: Committee Structure 
The first meeting was held on December 11, 1979, in conjunction with the organizational meeting involving all committees. At this meeting, Robert Sockwell of the American Institute of Architects Research Cooperation representing the American Institute of Architects was selected chairman of T.C. 8. Mark Swatta, representing the Interagency Committee on Seismic Safety in Construction and an employee of the Veterans Administration, was elected Vice Chairman. Tom Faison of the National Bureau of Standards was assigned to serve as Secretariat. Three meetings of T.C. 8 were held on December 11, 1979 at NBS in Gaithersburg, Maryland; February 19, 1980 at NBS Boulder Laboratories in Boulder, Colorado; and May 22, 1980 at NBS in Gaithersburg, Maryland.

The major issues addressed through comments from either members of T.C. 8 or the general public were: several items related to brittle materials and/or low flexural strength materials, and elevator design requirements. The issue of seviceability vs life safety and the impact of either philosophy was discussed, but remained an open issue determined to be outside the scope of individual Technical Committees. The Brick Institute of America submitted comments on matters related to brittle materials and/or low flexural strength materials and the serviceability philosophy. The National Elevator Industry submitted comments on elevator design requirements. The Prestressed Concrete Institute also pro rided several comments which were considered by the Committee, but the action taken in regard to these comments was to retain the existing wording in ATC 3-06.

Because the elevator design requirements were not adequately covered and could not be resolved at the Boulder meeting (Meeting 非), Chairman Sockwell assigned a Task Force to be chaired by George Gibson, and including Philip Lathrap, Christopher Arnold and Tom Wosser to draft a set of requirements to be considered by the full Committee. George Gibson circulated a set of recommendations that were taken from the proposed seismic regulations of ANSI A 17.1, the Elevator Safety Code. These recommendations were considered and acted upon at the third meeting of T.C. 8 on May 22, 1980 . A new section of Chapter 8 was developed, along with several modifications of material in other sections of the chapter which allowed the use of common formulas for any of the specified loading conditions.

The Committee acted to recommend to NBS and the Building Seismic Safety Council that Technical Committee 8 be retained through Phase II of the project to act in an advisory capacity on the planning and execution of Phase II.

For exact wording of the proposed changes, the reader is directed to Section 2, "Committee Actions." This report is intended to provide a record of actions taken by Technical Committee 8 during the proceeding of the review process. 
2.1 Recommendations for Change

TECHNICAL COMMITTEE: 非 ARCHITECTURAL MECHANICAL \& ELECTRICAL

ATC-3-06 SECTION REFERENCE: $\quad 8.2 .5$

First Letter Ballot

It em 1

'Section 8.2.5 to read: "Transverse or out-of-plane bending or deformation of a component or system which is subjected to forces as determined in Formula 8-1 shall not exceed the deflection capability of the component or system"

FINAL BALLOT: 8 YES

$$
\begin{aligned}
& -- \text { NO } \\
& -- \text { ABSTAIN } \\
& -- \text { DID NOT VOTE }
\end{aligned}
$$

COMMENT ON PROPOSED CHANGE :

The change is suggested as a more performance approach to cover a broad range of materials. 


\section{PROPOSED CHANGE}

TECHNICAL COMMITTEE : 非 ARCHITECTURAL, MECHANICAL \& ELECTRICAL

ATC-3-06 SECTION REFERENCE: Commentary 8.2 .5

First Letter Ballot

Item 2

${ }^{\circ}$ Commentary 8.2.5, third sentence to read: "This is particularly important for systems composed of brittle materials and/or low flexural strength materials."

FINAL BALLOT: 8 YES

$$
\begin{aligned}
& -- \text { NO } \\
& -- \text { ABSTAIN } \\
& -- \text { DID NOT VOTE }
\end{aligned}
$$

COMMENT ON PROPOSED CHANGE:

This change is editorial and was made for consistency. 


\section{PROPOSED CHANGE}

TECHNICAL COMMITTEE: \#8 ARCHITECTURAL MECHANICAL \& ELECTRICAL

COMMITTEE ITEM NUMBER:

$1 / 3$

ATC-3-06 SECTION REFERNCE: TABLE 8-B

First Letter Ballot

Item 3

'Table 8-B Footnote 4 changed to read: "Shall be raised one performance level if the area facing the exterior wall is normally accessible within a distance of 10 feet plus one foot for each floor height."

FINAL BALLOT: $\quad 8$ YES

-- NO
-- ABSTAIN
-- DID NOT VOTE

COMMENT ON PROPOSED CHANGE :

Footnote 4 changed to be more specific with regard to appendages and accessibility to areas near the appendages. 


\section{PROPOSED CHANGE}

TECHNICAL COMMITTEE: \#8 ARCHITECTURAL MECHANICAL \& ELECTRICAL

COMMITTEE ITEM NUMBER: $1 / 4$

ATC-3-06 SECTION REFERENCE: TABLE 8-B

First Letter Ballot

Item 4

"Table 8-B: Change entry "Veneers" to "Veneer Attachments"

FINAL BALLOT : $\quad 8$ YES

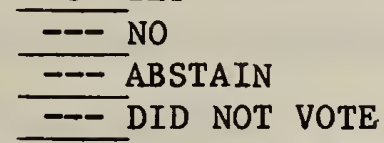

COMMENT ON PROPOSED CHANGE:

Editorial change to better reflect the intent of the entry in Table 8-B which is the "attachments" rather than the vaneer. 


\section{PROPOSED CHANGE}

TECHNICAL COMMITTEE: \#8 ARCHITECTURAL

COMMITTEE ITEM NO.: MECHANICAL \& ELECTRICAL

ATC-3-06 SECTION REFERENCE: $\mathbf{8 . 1}$

Seond Letter Ballot

Ballot Item 1

(New exception to be added to Section 8.1)

Exceptions:

3. Elevator systems which are in buildings assigned to Seismic Hazard Exposure Group I and are located in areas with a Selsmicity Index of 1 or 2 or which are in buildings assigned to Seismic Hazard Exposure Group II and are located in areas with Selsmicity Index of 1 are not subject to the provisions of this chapter.

FINAL BALLOT : 7 YES

\begin{tabular}{l}
$7-$ NO \\
-- ABSTAIN \\
\hline 1 DID NOT · VOTE
\end{tabular}

COMMENT ON PROPOSED CHANGE:

The additional "exception" was appropriately added to Section 8.1 so that the exceptions would be in one place. This new exception could have been placed in the new Section 8.4 but it was decided the better location would be in Section 8.1 . 
PROPOSED CHANGE

TECHNICAL COMMITTEE: \#8 ARCHITECTURAL, MECHANICAL \& ELECTRICAL

COMMITTEE ITEM NUMBER: $2 / 2$

ATC-3-06 SECTION REFERENCE: 8.4 (New Section)

Second Letter Ballot

Ballot Item 2

(New Section to be added to Chapter 8)

8.4 ELEVATOR DESIGN REQUIREMENTS

8.4.1 REFERENCE DOCUMENT

The design and construction of elevators and components shall conform to the requirements of ANSI Al7.1, American National Standard Safety Code for Elevators, Dumbwaiters, Escalators and Moving Walks, and the Proposed Al7 Seismic Regulations, except as modified by provisions of this chapter.

\subsubsection{ELEVATOR AND HOISTWAY STKUCTURAL SYSTEM}

Elevators and hoistway structural systems shall be designed to resist seismic forces in accordance with formula 8-1 and Table 8-B.

$W_{c}$ is defined as follows:

\begin{tabular}{l} 
Traction Car \\
\hline Counterweight $\mathrm{C}+.4 \mathrm{~L}$ \\
\hline Hydraulic \\
\hline $\mathrm{C}$ is weight of car \\
$\mathrm{L}$ is rated capacity \\
$\mathrm{W}$ is weight of counterweight \\
$\mathrm{P}$ is weight of plunger
\end{tabular}

\subsubsection{ELEVATOR MACHINERY AND CONTROLLER ANCHORAGE(S)}

Elevator machinery and controller anchorages shall be designed to resist seismic forces in accordance with formula $8-2$ and Table 8-C. 


\subsubsection{SEISMIC CONTROLS}

All elevators with a speed of $150 \mathrm{fpm}$ or greater shall be furnished with signaling devices as follows:

(a) A seismic switch device to provide an electical alert or command for the safe automatic emergency operation of the elevator system.

(b) A counter weight displacement or derailment device to detect lateral motion of the counterweight.

A continuous signal from (b) or a combination of signals from (a) and

(b) will initiate automatic emergency shutdown of the elevator system.

\subsubsection{RETAINER PLATES}

Retainer plates are required top and bottom of the car and counterweight except where safety stopping devices are provided. The depth of engagement with the rail shall not be less than the side running face of the rail.

\subsubsection{DEFLECTION CRITERIA}

The maximum deflection of guide rails, including supports, shall be limited to prevent total disengagement of the guiding members of retainer plates from the guide rails' contact surface.

FINAL BALLOT: 7 . YES

\begin{tabular}{l}
-- NO \\
-- ABSTAIN \\
\hline DID NOT VOTE
\end{tabular}

COMMENT ON PROPOSED CHANGE :

Because of the significance of elevator performance and potential cost impact, it was decided that a new section should be developed specific to "Elevator Design Requirements." The material has been developed so that the existing formulas and proposed seismic coefficients can be used in designing to resist seismic forces. 
TECHNICAL COMMITTEE : 非 ARCHITECTURAL MECHANICAL \& ELECTRICAL

COMMITTEE ITEM NUMBER: $2 / 3$

ATC-3-06 SECTION REFERNCE: TABLE 8-B

Second Letter Ballot

Ballot Item 3

1. Change entry under Partitions - "Elevators and Shafts" to Elevator Shafts. (Editorial)

2. Add the following new entry:

Architectural Components

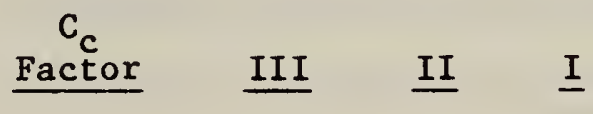

Elevator and Holstway Structural Systems

- Structural frame providing the

1.25

S

G G supports for gulde rafl brackets

- Guiderails and brackets

1.25

S

G G

- Car and counterweight guiding

1.25

S

G G

FINAL BALLOT: 7 YES

\begin{tabular}{l}
$7--$ NO \\
\hline-- ABSTAIN \\
\hline 1 DID NOT VOTE
\end{tabular}

COMMENTS ON PROPOSED CHANGE :

These new entries to Table $8-B$ allow general usage of equation $8-1$. 


\section{REVIEW AND REFINEMENT OF TENTATIVE SEISMIC PROVISIONS}

\section{PROPOSED CHANGE}

TECHNICAL COMMITTEE: \#8 ARCHITECTURAL COMMITTEE ITEM NUMBER: $2 / 4$ MECHANICAL \& ELECTRICAL

ATC-3-06 SECTION REFERENCE: TABLE 8-C

Second Letter Ballot

Ballot Item 4

1. Add the following new entry:

\section{Mechanical/Electrical Components}

Elevator Machinery and Controller Anchorage

FINAL BALLOT: 7 YES

\begin{tabular}{l} 
- NO \\
-- ABSTAIN \\
\hline 1 DID NOT VOTE
\end{tabular}

COMMENT ON PROPOSED CHANGE :

This new entry to Table $8-C$ allows the general usage of equation $8-2$.

$\begin{array}{llll}\begin{array}{c}C_{C} \\ \text { Factor }\end{array} & \text { III } & \text { II } & \frac{I}{\text { I }} \\ 1.25 & \text { S } & \text { G } & \text { G }\end{array}$




\subsection{Recommendations for Trial Design}

\section{None}

2.3 Recommendations for Commentary

None

\subsection{Other Recommendations}

None 
3.0 Committee Records

\subsection{Minutes of Meetings}

Meetings of the Technical Committee 8 were held on December 11, 1979 in Gaithersburg, Maryland, on February 19, 1980 in Boulder Colorado and on May 22, 1980 at Galthersburg, Maryland. Minutes of these meetings are presented below. 


\author{
Minutes of Meeting No. 1 Committee 8 \\ Architectural, Mechanical and Electrical \\ Tentative Seismic Provisions Project \\ National Bureau of Standards \\ Galthersburg, Md. \\ December 11, 1979
}

Members in attendance:

Name

Robert Sockwe11, Chalrman

Bruce 01sen

ShIgek1 Hiratsuka

Ph1lip Lathrap

Stephen Heath

Joseph Wintz

Mark Swatta, Vice Chairman

George Gibson

Tom Wosser

Christopher Arnold

Tom Falson, Secretarlat

Jim Shaver

V1sitors
Representative of

American Institute of Architects

American Society of Civil Engineers

American Soclety of Heating, Refrigerating and Alr Conditioning Engineers

American Society of Mechanical Engineering

American Soclety of Plumbing Engineers

Brick Institute of America

Interagency Committee on Selsmic Safety in Construction

National Elevator Industry, Inc.

Applied Technology Council

Bullding Seismic Safety Council

National Bureau of Standards

National Bureau of Standards

None

Tom Faison, as Secretariat, opened the meeting of Comittee 8 by asking that members introduce themselves, give their affiliation and some background material regarding professional interests. The first order of business was the election of. a chairman. After a short discussion, 
Mr. Sockwe11, the AIA representative, was nominated and elected without opposition. Mr. Sockwell requested that a vice chalrman be selected. Mr. Swatta, the ICSSC representatlve, was approved to Berve es vice chairman.

\section{Future Meetiag Location}

After considerable discussion, the Denver, Colorado area was selected as the site for the next weeting. The dates of February 19-20, 1980 were chosen. A two-day session is anticlpated and an attendance of 25-50 is projected. NBS will make arrangements for the meeting at the NBS Boulder site in Boulder, Colorado. If space 18 rot avallable at the Boulder site, the meeting will be held at the Denver Airyort. Notification of the meeting with details on time and locatlon wll be sent out at a later date.

\section{Resource Material}

Members requesting coples of ATC 3-06 and NBS Task Note 1100 were given coples of these reports at the meeting.

\section{Action Items}

There were several 1ssues discussed that required action.

Action by NBS

As a source of potential candidates to recelve announcements of the upcoming public meeting February 19-20, 1980, it was suggested that the ATC file be searched to make sure that individuals or organizations which made comments on the flrst generations of the ATC Provisions are made aware of the upcoming weetirig.

Response: This laformation will be useful in developing a distrubition list.

Action by NBS

It was requested that comments be assembled which were submitted during the earlier cycles of the ArC Piovisions and which relate to Committee 8 activities. These comerics should be clrculated to Comittee 8 members.

Response: Because of the large number of comments and the significant change in the document from earller drafts to 1ts present form 1t was declded that not all cowments would be clrculated. A number of comments have been chosen that are felt to be representative.

Note: The comltcee resolved that the comnents on earlier drafts are to be reviewed for information only and it is not the intent that the committee resolve or try to answer theser comments. 
Act1on by NBS

Prepare a complete listing of the membership list of Committee 8 giving addresses and telephone numbers. Membership list of the Coordinating Comittee was also requested.

Response: Membership list will be sent to members.

Action by NBS

Clarifiacation is needed on voting procedures. Can members of the comittee abstain from voting?

Response: Yes, but everyone is encouraged to vote.

Is the simple majority determined based upon the membership or those voting?

Response: The simple majority is based upon those voting, thus it is important that all members participate in voting upon issues.

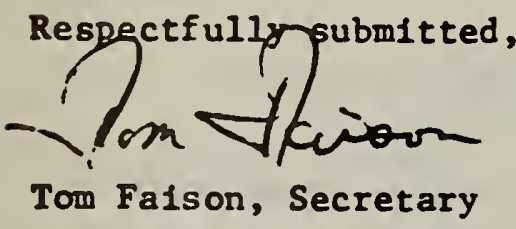


Minutes of Meeting No. 2 Committee 8

Architectural, Mechanical and Electrical

Tentative Seismic Provisions Project

National Bureau of Standards

Boulder, Colorado

February 19, 1980

Members Present:

Members Absent:

Robert Sockwe1l, Chairman

Shigeki Hiratsuka

Mark Swatta, Vice Chairman

Philip Lathrap

Joseph Wintz

George Gibson

Bruce 01sen

Stephen Heath

Tom Wosser

Chrístopher Arnold

Jim Shaver

Tom Faison

Visitors:

None

The Meeting was opened by Chairman Sockwell at 9:07 a.m.

The minutes of the December 11, 1979 meeting were accepted as distributed.

An issue was raised for discussion regarding those organizations that were listed as potential members of Committee 8 but had not sent representatives. The discussion dealt specifically with the status of participation for:

IEEE, NEMA and NFPA. The Secretary was directed to determine if the organizations had submitted a letter declining to participate.

1. Consideration of comments from the Brick Institute of America.

Comments were presented by Joseph Wintz.

Issue 1 Section 8.2.4 Component Deformation - Exception

ATC recommendation was accepted by BIA thus comment was withdrawn.

Issue 2 Section 8.2.5 Out-of-Plane Bending

Motion made by Wintz, seconded by Swatta.

Change 8.2.5 to read, "Transverse or out of plane bending or deformation of a component or system which is subjected to forces as determined in Formula 8.1 shall not exceed the deflection capability of the component or system." 
Change Commentary 8.2.5 third sentence to read "This is particularly important for systems composed of brittle materials and/or low flexural strength materials." Motion passed 5-0.

Issue 3 Table 8.B Seismic Coefficient and Performance Characteristic Levels Required for Architectural Systems or Components.

Several motions were proposed.

Motion was made to eliminate Footnote 4. Failed to pass.

Motion was made to retain current wording in Footnote 4. Failed to pass.

Motion was made to revise Table 8.B so that the $L$ for Exterior Nonbearing Walls and Wall Attachments be changed to $G$ and eliminate Footnote 4 and substitute Footnote 1 in place of 4 . Failed to pass.

Motion made by 01sen, seconded by Heath as follows, "Footnote 4 - Shall be raised one performance level if the area facing the exterior wall is normally accessible within a distance of 10 feet plus one foot for each floor height."

Motion passed 5-0.

Issue 4 Table 8. B Veneers

Motion by Wintz, seconded by Swatta.

Change "Veneers" to "Veneer Attachments."

Motion passed 5-0.

A suggestion was made that Committee 12 "Masonry" be made aware of the need for seismic design standards for veneers.

\section{Prestressed Concrete Institute Comments}

Issue 1 Section 8.2.3 Exterior Wall Panel Attachment

A motion was made by Swatta, seconded by Wintz that the ATC recommendation for no changes be accepted. Motion passed 5-0.

\section{Issue 2 Section 8.2.2 Forces}

Motion made by Swatta and seconded by Wintz, passed 5-0, to accept ATC recommendation for no changes. The argument was nonpersuasive as no specific reference was given for UBC-79 practice. 
Elevator Industry comments

It was agreed by Committee 8 that greater consideration of elevator requirements should be given. Chairman Sockwell appointed a task force to develop draft requirements. The task force is comprised of

Mr. George Gibson, Chairman, along with Mr. Philip Lathrap, Mr. Christopher Arnold and Mr. Tom Wosser. The draft requirements are to be circulated to the committee prior to the next scheduled meeting which is tentatively scheduled for Boulder, Colorado the last week of April 1980.

Action Items

1. Determine the official action taken with regard to IEEE, NEMA and NFPA participation on Committee 8 . Have these organizations declined to participate?

2. Prepare responses to the three sets of comments. Responses will include the ATC recommendation along with the action taken at the Boulder meetings.

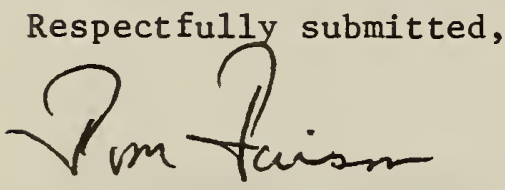

Tom Faison, Secretary

cc: Roland Sharpe

E.V. Leyendecker

E. O. Pfrang 
Minutes of Meeting No. 3 Committee 8

Architectural, Mechanical and Electrical

Tentative Seismic Provisions Project

National Bureau of Standards

Gaithersburg, MD

May 22, 1980

Members Present:

Robert Sockwe11

Mark Swatta

Shigeki Hiratsuka

George Gibson

Joseph A. Wintz, III

Tom Wosser

James Shaver

Tom Faison

Visitors:

None

The Vice Chairman Mark Swatta opened the meeting as Chairman Sockwell was delayed in arriving. The draft requirements prepared by George Gibson were distributed and studied since most members had insufficient time to prepare comments on the draft material on Elevator Design Requirements prior to the May 22 meeting. Mr. Gibson explained that the draft requirements, Tentative Seismic Provisions for Elevator Equipment, were summarized from the ANSI-A 17.1 Elevator Safety Code Proposed A 17 Seismic Regulations (copy attached).* Mr. Swatta raised issues related to the Tentative Seismic Provisions for Elevator Equipment, such as: how to deal with references; the application of provisions for different earthquake zones; the need to present the provisions in ATC format; and the extent of coverage needed for elevator design.

Through group discussion, it was decided that the elevator systems not subject to the ATC Tentative Provisions could be adequately described through the use of an additional exception which could be located in Section 8.1 of Chapter 8 . Reference can be made to attached Ballot Item (1) for exact wording.

It was proposed that a new Section 8.4 on Elevator Design Requirements be developed in the ATC format which would make use of the formulas the tables of Chapter 8. New material was developed from the ANSI A 17 Seismic Regulations which specifies "Wc" for various elements or components of elevators so that the existing relationship (Formula 8-1) can be used. New material is also proposed on: Seismic Controls; Retainer Plates; and Deflection Criteria. The attachment designated Ballot Item (2) presents the wording for the new proposed Section 8.4 .

Tables $8-B$ and $8-C$ were modified through slight changes in wording and the addition of new material for two entries, "Elevator and Hoistway Structural Systems" for Table 8-B and "Elevator Machinery Controller Anchorages" for Table 8-C. See attached Ballot Items (3) and (4) for detailed wording.

The letter which was circulated to the committee by Mark Swatta was discussed and it was recommended that Chairman Sockwell prepare a response to be directed to Dr. E. V. Leyendecker requesting that Technical Committee 8 be retained for use in an advisory capacity to react to proposed procedures and plans for carrying out Phase II of the project.

*

*Material not included as part of this report. 
Ballot Item 1

(New exception to be added to Section 8.1)

Section 8.1 GENERAL REQUIREMENTS

Exceptions :

3. Elevator systems which are in buildings assigned to Seismic Hazard Exposure Group I and are located in areas with a Seismicity Index of 1 or 2 or which are in buildings assigned to Seismic Hazard Exposure Group II and are located in areas with Seismicity Index of 1 are not subject to the provisions of this chapter. 
Ballot Item 2

(New Section to be added to Chapter 8 )

8.4 ELEVATOR DESIGN REQUIREMENTS

8.4.1 REFERENCE DOCUMENT

The design and construction of elevators and components shall conform to the requirements of ANSI Al7.1, American National Standard Safety Code for Elevators, Dumbwaiters, Escalators and Moving Walks, and the Proposed Al7 Seismic Regulations, except as modified by provisions of this chapter.

\subsubsection{ELEVATOR AND HOISTWAY STRUCTURAL SYSTEM}

Elevators and hoistway structural systems shall be designed to resist seismic forces in accordance with formula 8-1 and Table 8-B.

$W_{C}$ is defined as follows:

\begin{tabular}{l|l} 
Element & $\mathrm{W}_{\mathrm{C}}$ \\
\hline Traction Car & $\mathrm{C}+.4 \mathrm{~L}$ \\
\hline Counterweight & $\mathrm{W}$ \\
\hline Hydraulic & $\mathrm{C}+.4 \mathrm{~L}+.25 \mathrm{P}$ \\
\hline
\end{tabular}

C is weight of car

$\mathrm{L}$ is rated capacity

$\mathrm{W}$ is weight of counterweight

$P$ is weight of plunger

8.4.3 ELEVATOR MACHINERY AND CONTROLLER ANCHORAGE

Elevator machinery and controller anchorage shall be designed to resist seismic forces in accordance with formula 8-2 and Table 8-C. 


\subsubsection{SEISMIC CONTROLS}

All elevators with a speed of $150 \mathrm{fpm}$ or greater shall be furnished with signaling devices as follows

(a) A seismic switch device to provide an electrical alert or command for the safe automatic emergency operation of the elevator system. A counter weight displacement or derailment device to detect lateral motion of the counterweight. A continuous signal from this device or a combination of signals from (a) and (b) will initiate automatic emergency shutdown of the elevator system.

\subsubsection{RETAINER PLATES}

Retainer plates are required top and bottom of the car and counterweight except where safety stopping devices are provided. The depth of engagement with the rail shall be not less than the side running face of the rail.

\subsubsection{DEFLECTION CRITERIA}

The maximum deflection of guide rails, including supports, shall be limited to prevent total disengagement of the guiding members or retainer plates from the guide rails' contact surface. 

3.2 Roster

COMMITTEE 8: Architectural, Mechanical, and Electrical

American Institute of Architects

Mr. Robert Sockwell (Chairman)

AIA Research Corp.

1735 New York Ave., N.W.

Washington, D.C. 20006

Phone: 202-626-7441

American Society of Civil Engineers

$\mathrm{Mr}$. Bruce C. Olsen

1411 4th Ave. Bldg.

Suite 1420

Seattle, Washington 98101

Phone: 206-624-7045

American Society of Heating, Refrigerating and Air Conditioning Engineers

Mr. Shigeki Hiratsuka

406 South Barton

Arlington, VA 22204

Phone: 202-252-4950 (DoE) temporary

American Society of Mechanical Engineering

Mr. Philip Lathrap

c/o Pacific Gas and Electric Co.

77 Beale street

Room 2883

San Francisco, CA 94106

Phone: 415-781-4211 X1605

American Society of Plumbing Engineers

Mr. Stephen D. Heath, P.E.

American Society of Plumbing Engineers

15233 Ventura Blvd.

Suite 616

Sherman Oaks, CA 91403

Phone: 213-783-4845 
Committee 8 (continued)

Brick Institute of America

Joseph A. Wintz, III

Brick Institute of America

1750 0ld Meadow Lane

McLean, VA 22101

Phone: $703-893-4010$

Interagency Commtttee on Selsmic Safety in Construction

Mr. Mark Swatta

Verterans Administration (085A)

810 Vermont Avenue, N.W.

Washington, D.C. 20420

Phone: 202-389-3103

National Elevator Industry, Inc.

Mr. George Gi,bson

Otis Elevator Company

440 Fanklin Turnpike

Mahwah, NJ 07430

Phone: 201-825-4400

Applied Technology Counct1

Mr. Tom Wosser

H. J. Degenkolb Assocs.

350 Sansome St.

San Francisco, CA 94104

Phone: 415-392-6952

Butlding Setsmic Safety Counct1

Mr. Christopher Arnold

Building Systems Development Inc.

120 Broadway

San Francisco, CA 94111

Phone: $\quad 415-434-3830$ 


\section{National Bureau of Standards}

Mr. Tom Faison

Secretariat

Tentative Seismic Provision Project

Committee 8, Architectural, Mechanical and Electrical

National Bureau of Standards

Room B-168, Bldg. 226

Washington, D.C. 20234

Phone: $301-921-3293$

Dr. James R. Shaver

Tentative Seismic Provision Project

Committee 8, Architectural, Mechanical and Electrical

Nationa 1 Bureau of Standards

Room B-168, B1dg. 226

Washington, D.C. 20234

Phone: $301-921-2186$ 
3.3 Selected Committee Correspondence and Applied Technology Council Comments Presented below are several correspondences transmitted or recelved during the course of the Committee's actions.

1. ATC Comments on Chapter 8, ATC 3-06, Tom Wosser (recommendations related to comments received, Attachment A, not included)

2. Trial Design Issue for Technical Committee 8,

2a. - Swatta's letter of May 14, 1980

2b. - Olsen's letter of May 19, 1980

2c. - Kirkland's letter of June 23, 1980 
H. J. DEgENKolb \& ASSOCIATES. ENGINEERS

350 SANSOME STREET SAN FRANCISCO, CALIFORNIA 94104 !?

TELEPHONE 392-6952

TO: MEMBERS OF COMMITTEE 8 - ARCHIFCLLRAL, MECHANICAL AND ELECTRICAL OF THE NBS TENTATIVE SEISMIC PROVISION PROJECT R. GORDON DEAN GEORGES E. BASSETT THOMAS D. WOSSER LORING A. WYLLIE. JR. TED J. CANON GEORGE E. GREENWOOD CHRIS D. POLAND

February 11, 1980
HENRY J. DEGENKOLE

\author{
Tom Faison, Secretary \\ Robert Sockwell, Chairman \\ Bruce Olsen \\ Shigeki Hiratsuka \\ Philip Lathrap \\ Stephen Heath
}

Joseph Wintz

Mark Swatta

Christopher Arnold

James Shaver

George Gibson

From: Tom Wosser, ATC Representative

Reference: COMMENTS ON CHAPTER 8, ATC 3-06

Gentlemen:

We have received only three sets of comments, those from Brick Institute of America, Otis Elevator and the Prestressed Concrete Institute. You have all received copies of the comments, so I will not repeat them here except to refer to the organization, section number and section title.

\section{BRICK INSTITUTE OF AMERICA}

\section{- Section 8.2.4 COMPONENT DEFORMATION - EXCEPTION}

I disagree with the comment. Exception 1 in Section 8.1 does not except al1 "L" performance level components.

\section{- Section 8.25 OUT-OF-PLANE BENDING}

This section was an attempt to apply deflection limitations to wall framing systems, for out-of-plane bending. Although the commentary refers to "conventional limits based upon deflections as a proportion of the span", the Provisions themselves do not include any design criteria. In my opinion, Section 8.2 .5 does not add anything to Section 8.2. It is merely a "flag".

The comment refers to a masonry veneer system. Certainly, if the veneer is properly attached to the framing elements of the system, it is the framing elements themselves that would have to meet the design requirements. I do not believe the recommended change accomplishes anything particularly significant. 
Perhaps a better solution is to include a specific section such as that proposed for the new State of California Title 24:

TABLE NO. 2 23-L

Maximum Allowable Deflection Normal to the Surface of Wall Element Under Lateral Force Loading

\section{Wa11 Element \\ Loading \\ Condition}

Exterior Walls-brittle construction.......Seismic or Wind

Exterior Walls-flexible construction......Seismic or Wind

Veneered Stud Walls (Wood or Metal Studs):

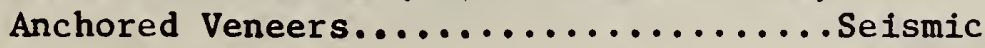

Max. Allow. Deflection*

$\mathrm{L} / 240$

$\mathrm{L} / 180$

$L / 600$

* $\mathrm{L}$ is the span between vertical or horizontal supports.

\section{- Table 8-B}

(a) Performance Level of Exterior Nonbearing Walls

For Seismic Hazard Exposure Group I, the committee intended a higher performance characteristic for exterior nonbearing walls as well as for wall attachments if the building is located in an urban area. I recommend that the footnote should remain.

(b) Veneers

The $C_{C}$ factor for veneers was based on the traditional $100 \% \mathrm{G}$ at working stress design for UBC Zone 4 conditions. Considering the workmanship factors, exposure to weather conditions and occasional unfortunate experience observed in building facade performance, I recommend that the $C_{c}$ factor remain at 3.0 .

Perhaps the Masonry section should include some specific veneer requirements such as those contained in UBC.

\section{OTIS ELEVATOR COMPANY}

\section{- General}

It was not the intent of ATC 3-06 to increase design requirements for elevator systems beyond those normally in use in California today. The points discussed by Otis Elevator are well taken and serve to point out that elevators "fell between the cracks" or perhaps "down the shaft" in the sometimes conflicting efforts of the architectural subcommiteee and the mechanical and electrical subcommittee. This oversight will require a significant change to ATC 3-06 requirements for elevators. 
In the State of California, the controlling requirements are contained in "Title 8 Elevator Safety Orders". These requirements are repeated in Part 7 of Title 24. "The proposed new Title 24 contains specific recommendations for elevators. (See Attachment A.) I suggest that these be modified as required to suit the format for incorporation into ATC 3-06. The $C_{c}$ factors can be adjusted accordingly and the requirements for "Earthquake Emergency Operation" needs to be considered for the various performance characteristic levels.

I would certainly agree that any certification of any mechanical, electrical, or elevator "components" should be at the operating unit assembly level, rather than each individual part.

- Section 8.3.2 FORCES

The requirements should be modified to conform to California Elevator Safety Orders.

- Section 8.3.2 FORCES

These factors are all defined. "hx" refers to the level under consideration and $\mathrm{hn}$ refers to the top level.

There should not be any variation with height for guiderail or guiderail connection design.

\section{- Section 8.3.2 FORCES}

Yes, horizontal and vertical forces are assumed to be simultaneous.

\section{- Section 10.2 STRENGTH OF MEMBERS}

(a) $\varnothing$ for elevator framing beams would be 0.90 , yielding $f_{b}=F_{y}$.

(b) The allowable shearing stresses for bolts might be covered under special elevator design requirements.

\section{PRESTRESSED CONCRETE INSTITUTE}

- Section 8.2.3 EXTERIOR WALL PANEL ATTACHMENT

I disagree with this comment. $C$ value for wall attachment is already high and beyond this, detailing ductility is the important requirement. 
- Section 8.2.2 FORCES

I disagree with this comment. The $F_{p}$, on parts of structures, is normally considered as a horizontal force, from any direction.

Very truly yours,

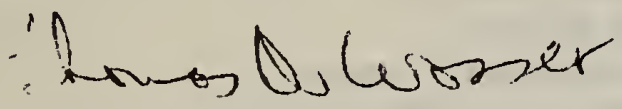

Thomas D. Wosser

$\mathrm{TDW} / \mathrm{dq}$

cc: Roland Sharpe 


\title{
Veterans
}

\section{Administration}

May 14, 1980

To Members of Technical Comittee 8, Architectural, Mechanical \& Electrical - Tentative Seismic Provisions

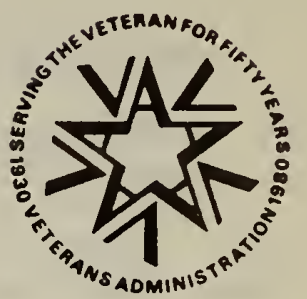

\author{
Robert Sockwell \\ Bruce C. Olsen \\ Shigeki Hiratsuka \\ Stephen D. Heath \\ Joseph A. Wintz, III \\ Philip Lathrap
}

George Gibson

Tom Wosser

Christopher Arnold

James R. Shaver

Tom Faison

Dear Member:

SUBJECT: Trial Design Issues for Technical Committee 8

The representatives of the Interagency Committee on Seismic Safety in Construction met on May 6, to disucss the ATC-3-06 design provisions. An extension of Technical Committee 8 scope was discussed as outlined in paragraph \#l on the attached sheet. We ask that you consider this suggestion as a topic for discussion at our next meeting on May 22, 1980.

Sincerely,

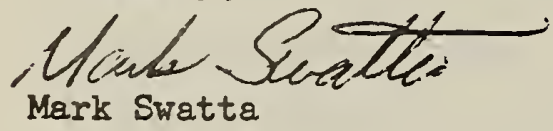

Attachment

cc: Dr.Charles C. Thiel 
Washington. D.C. 20472

May 6, 1980

Mr. William Moore

Chairman, Building Seismic

Safety in Construction Council

1015 15th Street, N.W.

Washington, D.C. 20005

Dear Bill:

On May 6 the Interagency Committee on Seismic Safety in Construction representatives met to discuss our participation in the nine subcommittees currently considering the ATC 3-06 design provisions. We reiterate the points made in our March 27 letter and ask that the recommendations contained therein be reviewed at the earliest possible time. We believe these points should be made to the subcommittees prior to their recommendations being balloted. We have three additional points to make:

1. Subcomittee 8 on Architectural, Mechanical and Electrical systems has apparently not considered how trial designs may be useful in judging the efficacy of their recommendations. To the best of our knowledge, ATC's proposed trial design_program. will only deal with structural systems. The incorporation into these design provisions architectural, mechanical and electrical considerations is a major innovation. Thus, we strongly recommend that the subcommittee give consideration to the trial design issue and make such recommendations, as appropriate, to the Coordination Committee.

2. Our representative to Subcommittee 9, Regulatory Use, has left us with a concern about whether the Subcommittee will resolve the issues before it in a timely manner. There appears to be a large number of issues still before the Comittee. We urge that the Council encourage the Subcomnittee to complete its work at the same time that the other Subcommitree's are completing theirs.

3. We have some concern that Subcomnittee 4, Concrete, is proposing to expand Chapter 11 to include precast and prestressed concrete. Yet the design provisions are not fully developed nor have they been experimentally validated. We are concerned that this potentially represents a signification departure from the original intent of review and refinement of the ATC Design Provisions for which we can not make legitimate technical arguments.

In net, we believe that the Subcommittees are working well and expect them to recommend a thoughtful, technically competent set of provisions for consideration by the Council membership.

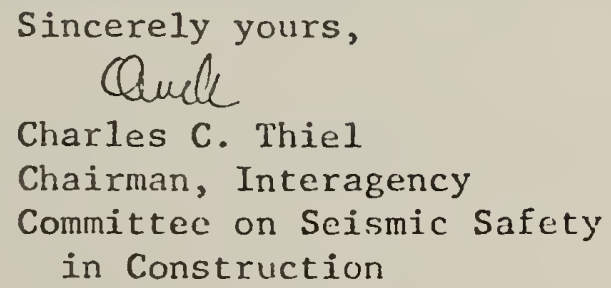

CC: ICSSC Representatives on Subcomnittees

E. Prang/R. Wright/E. Leyendecker/R. Johnson 


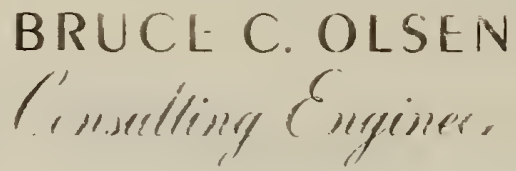

1411 FOURTH, VENUE

SI ATT:E, WASHINGTON 93101

$1206 ! 624 \quad 045$

May 19, 1980

Mr. Tom Faison, Secretary

Technical Committee 8 - Tentative Seismic Provisions

National Bureau of Standards

Room Bl68, Building 226

Washington, D.C. 20234

Subject: Trial Design Issues for Technical Committee 8

\section{Dear Tom:}

I have just receivad a letter dated May 14, 1980, from Mark Swatta, accompanied by an enclosure making reference to trial designs relating to architectural mechanical and electrical systems. You have received a copy of the same material.

The ATC proposal for the trial design program is basically aimed at the siructural systems it is true. At the same time, incorporated in the proposal there has been a segment relating to investigation of architectural, mechanical and electrical systems in conjunction with at least a part of the structures undergoing the trial design. While these "non-structural" systems are nominally separate from the basic structural supporting and resisting system, the response to the requirements is ordinarily ultimately referred back to a structural engineer. This may not necessarily be the original design engineer for the building, but it will be a structural design function. In view of the fact that the fundamental data concerning the trial design structures will be developed by the contractor performing the trial design, such information as fundamental period, higher modes, and related information will be developed by the basic contractor, it would appear that an extension of that work could conveniently incorporate questions raised through Subcommittee 8.

While I sit on this committee as a representative of ASCE, I must also admit to being a member of the Board of Directors of the Applied Technicology Council at the present time. If the Committee will overlook this potential for bias, they may accept the suggestion that the response to "non-structural " problems can very well be handled within the ATC proposal. I am sure that any suggestions relative to specific problems 
Mr. Tom Faison

May 19, 1980

Page Two

which might be submitted by the Committee to the Coordination Committee, if also directed to the Applied Technology Council, would be gratefully received and carefully considered by that body in administering the evaluation program.

Very truly yours,

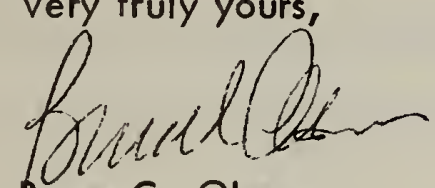

Bruce C. Olsen

BCO:br

cc: Roland L. Sharpe

Applied Technology Council 


\section{BUILDING SEISMIC SAFETY COUNCII. \\ 1015 15th Street, N.W' Suite? \\ Washington, D.C. 20005 \\ (202) 347.5710}

June 23,1980

To: NBS Technical Committees for the Review and

Refinement of Tentative Seismic Provisions

for Buildings

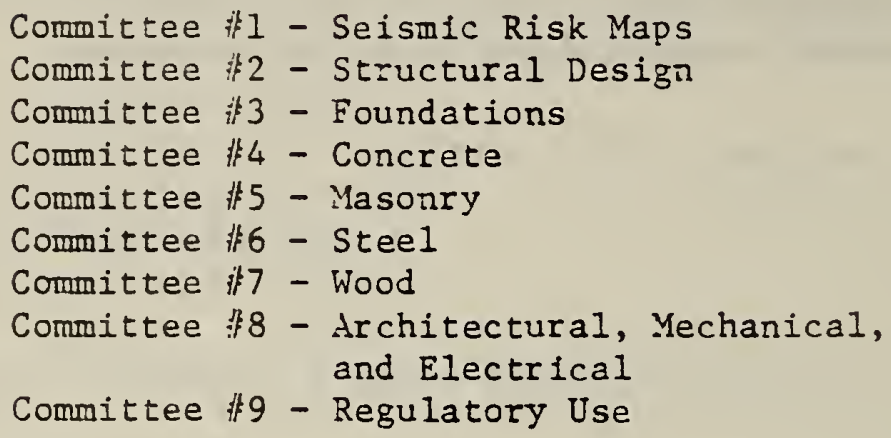

Enclosed is a copy of the first Building Seismic Safery Council newsletter. You will note that on page 3 under "work Plan Comittee" that the NBS Technical Committees 1 through 9 have been retained as Building Seismic Safety Council comittees.

A new ad hoc Committee 10-A, comprised of members of the existing Coordinating Comittee $\$ 10$ and the Structural Design Committee $\# 2$, with several additional organizational representatives, has been established. Your conmittees will continue their dutles through the completion of the trial designs and development of sultable and appropriate design provisions.

The funding for the trial design phases of the committee work will be included in the FY ' 81 proposal to the Federal Emergency Managenent Agency (FEMA).

WGK: Ib

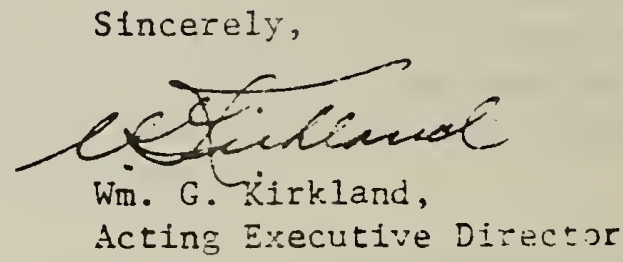

Enclosure

cL: BSSC Board of Direction - no enclosure BSSC Work Plan Committee- no enclosure BSSC Overview Committee - no enclosure Gene C. Brewer Edward O. PErang Charles C. Thie! E. V. Leyendecker 


\begin{tabular}{|c|c|c|}
\hline $\begin{array}{l}\text { U.S. DEPT. OF COMM. } \\
\text { BIBLIOGRAPHIC DATA } \\
\text { SHEET }\end{array}$ & $\begin{array}{l}\text { 1. PUBLICATION OR REPORT NO. } \\
\text { NBSIR } 80-2111-8\end{array}$ & 3. Recifient's Accession No. \\
\hline \multirow{3}{*}{\multicolumn{2}{|c|}{$\begin{array}{l}\text { 4. TITLE AND SUBTITLE } \\
\text { Review and Refinement of ATC 3-06 Tentative Seismic Provisions } \\
\text { Report of Technical Committee 8: Architectural, Mechanical } \\
\text { and Electrical }\end{array}$}} & 5. Publication Date \\
\hline & & October 1980 \\
\hline & & 6. Performing Organization Code \\
\hline \multicolumn{2}{|l|}{$\begin{array}{l}\text { 7. AUTHOR(S) } \\
\text { Thomas K. Faison }\end{array}$} & 8. Performing Organ. Report No. \\
\hline \multirow{2}{*}{\multicolumn{2}{|c|}{ 9. PERFORMING ORGANIZATION NAME AND ADDRESS }} & 10. Project/Task/Nork Únit No. \\
\hline & & 11. Contract/Grant No. \\
\hline \multirow{2}{*}{\multicolumn{2}{|c|}{$\begin{array}{l}\text { 12. SPONSORING ORGANIZATION NAME AND COMPLETE ADDRESS (Street, City, State, zIP) } \\
\text { Federal Emergency Management Agency } \\
\text { Washington, D.C. } 20472\end{array}$}} & $\begin{array}{l}\text { 13. Type of Report \& Period Covered } \\
\text { Fina1 }\end{array}$ \\
\hline & & 14. Sponsoring Agency Code \\
\hline
\end{tabular}

15. SUPPLEMENTARY NOTES

Document describes a computer program; SF-185, FIPS Software Summary, is attached.

16. ABSTRACT (A 200-word or loss factual summary of most significant information. If documert includes a significant bibliography or literature survey, mention it here.)

The TENTATIVE PROVISIONS FOR THE DEVELOPMENT OF SEISMIC REGULATIONS FOR BUILDINGS were developed by the Applied Technology Council to present, in one comprehensive document, current state-of-knowledge pertaining to seismic engineering of buildings. The TENTATIVE PROVISIONS are in the process of being assessed by the building community. This report is one of a series of reports that document the deliberations of a group of professionals jointly selected by the Building Seismic Safety Council and the National Bureau of Standards and charged with reviewing the TENTATIVE PROVISIONS prior to the conduct of trial designs. The report contains recommendations and records of the committee charged with the review of the material related to architectural, mechanical and electrical provisions. The committee made seven general recommendations for revision and one recommendation for the addition of a new section on elevator design requirements. These recommendations by Committee 8 were made to the parent group, the Joint Committee on Review and Refinement, and their action on these recommendations is documented in a companion report.

17. KEY WORDS (six to twelve entries; alphabetical order; capitalize only the first letter of the first key word unless a proper name; separated by semicolons)

Architectural; electrical; elevators; mechanical; seismic coefficients

\begin{tabular}{|c|c|c|}
\hline $\begin{array}{l}\text { 18. AVAILABILITY }[\bar{X} \text { Unlimited } \\
\square \text { For Official Distribution. Do Not Release to NTIS }\end{array}$ & $\begin{array}{l}\text { 19. SECURITY CLASS } \\
\text { (THIS REPORT) } \\
\text { X } \\
\text { UNCLASSIFIED }\end{array}$ & $\begin{array}{l}\text { 21. NO. OF } \\
\text { PRINTED PAGES }\end{array}$ \\
\hline $\begin{array}{l}\text { [] Order From Sup. of Doc., U.S. Government Printing Office, Washington, DC } \\
20402 \text {, SD Stock No. SNO03-003- }\end{array}$ & $\begin{array}{l}\text { 20. SECURITY CLASS } \\
\text { (THIS PAGE) }\end{array}$ & 22. Price \\
\hline $\begin{array}{l}\text { X Order From National Technical Information Service (NTIS), Springfield, } \\
\text { VA. } 22161\end{array}$ & UNCLASSIFIED & \\
\hline
\end{tabular}



: 
